\title{
Homosocial stewardship: the opposed and unpaid care work of women water stewards in West Virginia, USA
}

\author{
Martina Angela Caretta $^{1}$
}

\begin{abstract}
The identity of people living in Central Appalachia is tightly connected with water. Because of the threats to water resources due to coal mining, and most recently, hydraulic fracturing and oil and gas pipeline projects, citizens have formed several nonprofit organizations to preserve or restore rivers and watersheds. Notably, women head the biggest, state-wide, most active and visible of these organizations. Grounded in 25 in-depth interviews with female water stewards in West Virginia, this article examines nurturing approaches, financial impediments, and opposition that make water stewardship in West Virginia essentially homosocial care work. Expanding on the knowledge-agency-care stewardship framework, this article contributes to the under-researched dimension of care. It also suggests that the analytical lens of homosociality is fruitful to understand the gender and power dynamics that hamper water stewardship in WV. Finally, it challenges the renewed stereotyping and essentializing of Appalachia through the representation of women as passive, ignorant, bound to their homes, victims of overdoses, sexual trafficking, and violent marital relationships by showing how, against material and societal odds, women persist in their care for water.
\end{abstract}

Key Words: homosociality; stewardship; water; watershed organizations; West Virginia; women

\section{INTRODUCTION}

On 12 February 2018, Lissa Lucas, a West Virginia resident, spoke at a public hearing on bill HB4268, which allows companies to drill on private land with the consent of $75 \%$ of landowners. Lucas spoke and listed the financial contributions delegates had received from the industry. When asked to stop sharing "personal comments" about delegates on the floor, she persisted. Finally, she was escorted out of the House chambers. Her message, however, was not silenced, but rather made news (Nobel 2018). In this article, I will show how this episode is representative of women's water stewardship in West Virginia.

The history of Appalachia is the history of coal extraction and, although employment has declined in the mining sector in West Virginia since the 1960s, the identity of the state remains deeply tied to natural resource extraction. Appalachia is still engrained today in a complex web of economic and social relations that make it a poignant case study of the role that civic society plays in environmental stewardship. In previous decades, environmental activists were contesting ongoing mining operations (Bell and Braun 2010). Today they are mostly concerned with remediating the postmining landscape. People's health is not only threatened by the pollutants resulting from mining, but also by potential spills due to chemical industry incidents, hydraulic fracturing, or gas pipeline construction.

Since the 1970s, health and environmental concerns have triggered women's activism in Appalachia against coal mining (Smith 2015). However, often because of their social positioning women are constrained in their participation and in their capacity of making effective leeway in environmental policy making (Dyer 2018). Based on this literature and original data and, departing from Enqvist et al.'s (2018) care-agency-knowledge framework of stewardship, this article contributes to the study of the dimension of care within this framework. Specifically, I examine nurturing approaches, financial impediments, and opposition that exemplify, I argue, that women's water stewardship in West Virginia is essentially homosocial care work.
This study builds on extensive literature that has documented women's environmental activism in Appalachia (e.g., Bell and Braun 2010, Smith 2015) by reasserting the crucial role that women have and have historically had in the preservation of natural resources and, in this case, particularly water in Appalachia. This renewed focus is significant in a time when the stereotyping and essentializing of Appalachia has been re-enacted through the representation of women as passive, ignorant, bound to their homes, victims of overdoses, sexual trafficking, and violent marital relationships (Lofton 2018). This work challenges these preconceived notions and stereotypes by showing how, against material and societal odds, women persist in their care for water.

\section{HOMOSOCIAL STEWARDSHIP}

Recognizing the numerous existing meanings of stewardship (Bennett et al. 2018, Enqvist et al. 2018), the definition adopted in this article is "the responsible use of natural resources in a way that takes full and balanced account of the interests of society, future generations and other species, as well as of private needs, and accepts significant answerability to society" (Worrell and Appleby 2000:269). Although this phenomenon can take different forms at a variety of scales (Bennett et al. 2018), stewardship in this article focuses on women that are part of self-organized watershed groups or state-wide organizations for the management and protection of water (Worrell and Appleby 2000, Barry and Smith 2008, Svendsen and Campbell 2008). These groups are part of a "vibrant backyard environmentalism" (Svendsen and Campbell 2008:1) that often manage community-based resources because of local environmental and quality of life concerns.

Recognizing the need for human beings to extract natural resources for societal development, collective ecological management is geared toward long lasting and sustainable ways to work with the environment rather than against it (Barry and Smith 2008, Bennett et al. 2018). According to Enqvist et al. (2018), stewardship lies at the intersection of care, knowledge, and agency. Care signifies the emotional and value-laden 
attachment and responsibility that motivates the steward to work for the preservation of the environment. Knowledge denotes the information and notion that stewards earned during his/her engagement with the environment s/he wants to preserve. Agency implies stewards can shape and influence the social-ecological conditions of the environment they are working to preserve. As suggested by Enqvist et al. (2018), outlining stewardship along these three focus areas allows researchers to further examine one dimension of collective ecological management.

This article contributes to the stewardship framework by focusing on the under-researched dimension of care, focusing particularly on gender. Enqvist et al. (2018:25) states this focus can help explore "how rationalized ideals of stewardship interact with financial incentives, sense of belonging, and perceptions of ecological change, to shape stewardship action in particular contexts." In this article, I examine how care is manifested in women's activities and "nurturing approaches" (Enqvist et al. 2018:25) notwithstanding financial disincentives and opposition.

Stewards in Appalachia are often women who through their voluntary unpaid labor, restore water polluted by abandoned mine drainage, to preserve it from excessive industrial withdrawal for energy extraction and ensuring recreational access for future generations' benefit. These goals, however, are in contrast with the extractive economic model on which the state of West Virginia has been built relying on mostly male miners. In this context, I suggest that the analytical lens of homosociality is fruitful to understand the gender and power dynamics that hamper water stewardship in West Virginia. Homosociality refers to single gender networks that underpin normative prescriptions about gender roles and power dynamics among genders, ultimately reinforcing women's position as subordinate (Bird 1996). The lens of homosociality has been applied in the study of masculinity and patriarchy in organizations and relationships between genders, (e.g., Holgersson 2013, Hammarén and Johansson 2014), but not in the context of environmental organizations. Specifically in relation to water, women's participation in water management organizations has been explored from the wider perspective of gender theory (e.g., Joshi 2014, Mandara et al. 2017) but without incorporating the concept of stewardship. Hence, by investigating women's homosocial networks in water stewardship in West Virginia, this article contributes not only to the further exploration of care in the agency-knowledge-care stewardship framework, but it also adds to the understanding of homosociality in female headed organizations.

\section{METHODS}

In 2017, I gathered the name, location, and leadership data of environmental and watershed organizations in West Virginia through internet searches of key terms, such as "water conservation," and "environmental protection." I then adjusted the list by removing those organizations whose focus was not on water stewardship. This search brought forward numerous organizations whose focus is on larger rivers and watersheds in the state. Several of these large organizations were affiliated with the West Virginia Conservation Agency, which, under the West Virginia Watershed Network (WVWN) section of its web site, had a seemingly updated list of active and nonactive organizations. After compiling a working list of organizations, I cross-checked with the contact information from the WVWN list by visiting each organization's web site to see if they were active. All organizations were different in size and in area of influence - government (West Virginia Department of Environmental Protection [WVDEP]), statewide NGOs, and watershed focused NGOs - but had the same objectives and goals. The list consisted of 175 organizations, of which 104 were active, meaning they had an active web or Facebook page, had organized an event/meeting in the last 12 months, had a functioning phone number, and staff available via phone and/or email. These data were crucial in identifying leadership and its gender ratio, and contacting women engaged in water stewardship in WV.

Of these 104, 44 are headed by women and 60 by men (Fig. 1). Notably women head tristate, state-wide, and most active watershed organizations. Moreover, the wide majority of those organizations whose director is a man are constituted mostly by women at the lower ranks and women are often the spokespersons and the most visible face of these organizations. A series of videos by WVDEP on watershed organizations in the state and recent documentaries (e.g., Hoback 2017) on the state of water in West Virginia also confirm this. Additionally, during the West Virginia legislative session, these same women constitute the environmental and water lobby, often made up solely of women. Hence, although they might be a minority in terms of the number extrapolated above, they are actually considerably more active and visible than men as water stewards in West Virginia.

I first contacted women in leadership positions, i.e., director, assistant director, of the most recognizable and visible water protection organizations around the state, e.g., WV Rivers, Ohio Valley Environmental Coalition (OVEC), and the WVDEP Division of Water \& Waste Management (Fig. 2). Following, snowball sampling was used with the goal of representing women in different organizations, i.e., small, mostly volunteer-based watershed organizations, state-wide NGOs, and in different positions, e.g., employed, leaders, volunteers, board members, across the state. I interviewed 25 women in 2017 until I reached data saturation. I would get the same answers for the questions I was posing, independently of the position that the interviewee had, and I was referred back to the same group of women for interviews.

Semistructured interviews stretched from 45 minutes to 2 hours, with women ranging from 25 to 75 years of age. The interviews focused on women's educational background; their occupational history; the reasons why they had become water stewards; what their biggest win/loss was; and what were the most challenging aspects of their work. Interviews were recorded, transcribed, and shared with interviewees who confirmed their content and willingness to have data used for publication. Transcriptions were added into the qualitative data analysis software NVIVO and coded for emerging themes by a graduate student, striving for inter-rater reliability. The codes used for this article were activities, employment, and opposition. I developed summaries of these themes and shared with interviewees in a member checking session during the first weekend retreat for women in the water sector in West Virginia during September 2018. The content of the summaries was discussed in one focus group setting and member checked by 18 participants, some of which had been interviewed, while others had not because they were not available during the data gathering period or because data saturation had 
Fig. 1. Geographical location of the 104 active water organizations in West Virginia, gender of their leadership, and location of interviewees' organizations.

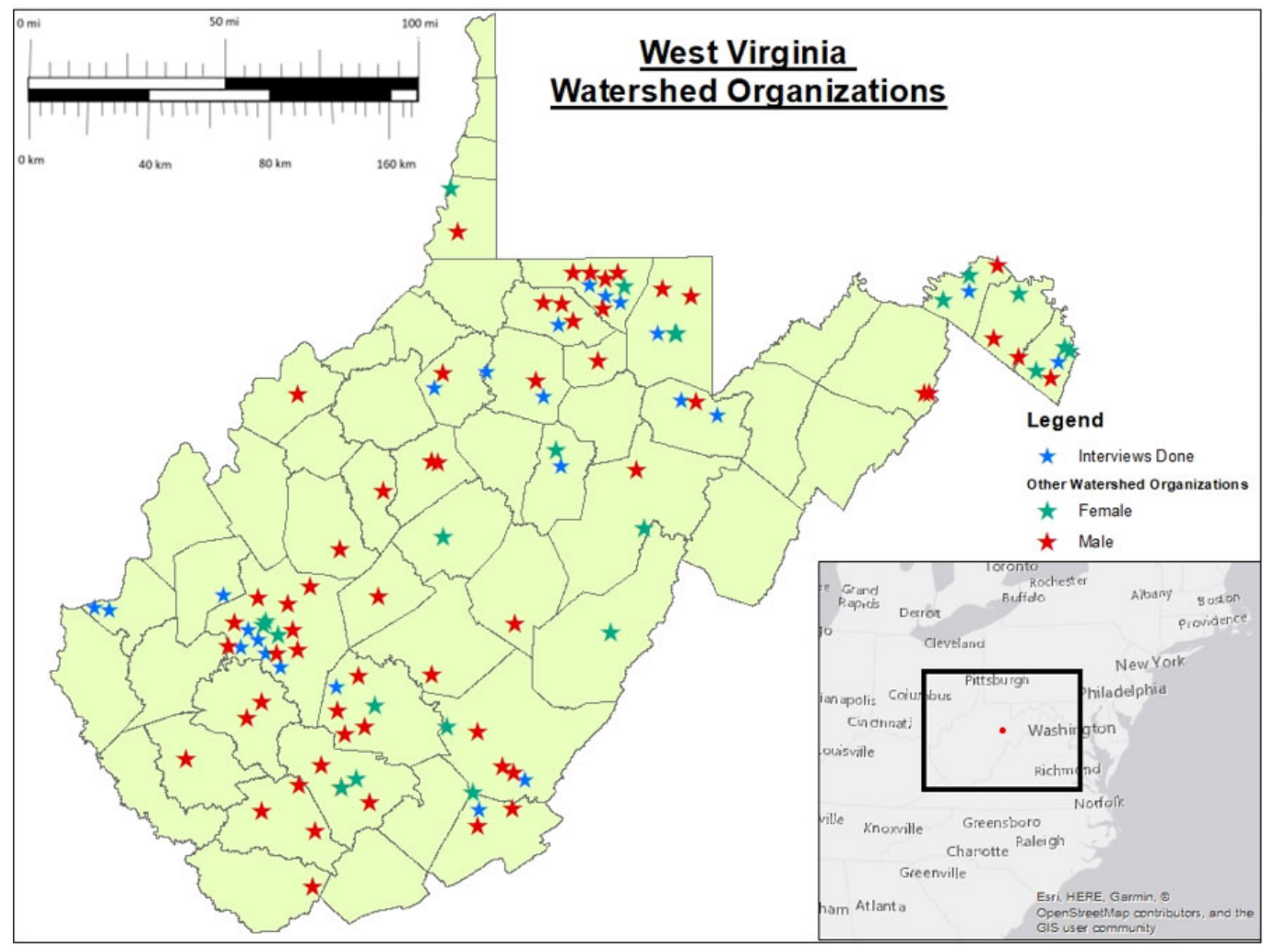

already been reached. Member checking ensured transactional validity, i.e., validated data and preliminary analysis with input from participants. The advantages of this method include the opportunity to collect more data as participants provide feedback on the analysis, and to both validate and conversely complicate data analysis (Caretta 2016).

Fig. 2. Typology of organizations and composition of organizations; data gathered from the top six staff positions for each organization. (DEP, Department of Environmental Protection, Division of Water \& Waste; OVEC, Ohio Valley Environmental Coalition; WV Rivers, West Virginia Rivers; FOC, Friends of the Cheat).

\begin{tabular}{|c|c|c|c|c|c|}
\hline \multicolumn{2}{|c|}{ Organization } & $\begin{array}{c}\text { Government } \\
\text { (DEP) }\end{array}$ & $\begin{array}{c}\text { Tri State } \\
\text { NGOs } \\
\text { (OVEC) }\end{array}$ & $\begin{array}{c}\text { Statewide } \\
\text { NGOs } \\
\text { (WV Rivers) }\end{array}$ & $\begin{array}{c}\text { Watershed } \\
\text { Focused } \\
\text { NGOs } \\
\text { (FOC) }\end{array}$ \\
\hline $\begin{array}{c}\text { Gender of those } \\
\text { in the top six } \\
\text { positions in their } \\
\text { respective } \\
\text { organizations }\end{array}$ & Male & 4 & 2 & 1 & 3 \\
\cline { 2 - 6 } & Female & 2 & 4 & 5 & 3 \\
\hline
\end{tabular}

\section{RESULTS: WOMEN WATER STEWARDS' CARE}

Care drives stewards' heightened ethical sense to construct and maintain a harmonic relationship between people and the environment. They do so through approaches that foster a vision of the environment as a common good that needs to be preserved and restored. Activities that promote this vision are possible thanks to financial and social encouragements (Bennett et al. 2018).

Nurturing approaches

Women are guided in this work by their care for the environment and future generations. Some women describe themselves as nurturing and approachable adding:

I think there's something about the feminine psyche that is either more in tune with the earth and the problems that the earth might be having, almost intuition-kind of thing, or it may be kind of our maternal aspects of caregiving and nurturing young and all that that put us there. I don't know exactly what that makes it that way, but I know that it is definitely not a coincidence. (Interviewee \#11, 17 May 2017)

It's in my DNA that I want to see justice, fairness, and equality. ... I've been in activism all my life. (Member checking session, 22 September 2018)

These statements encapsulate women's motivation for engagement: they care. They care about future generations and the environment because of an intrinsic, ethical, and emotional connection with their surroundings that pushes them to act. Women put into action these nurturing feelings through a set of diverse activities that can be categorized as advocacy, education, programming, and organizing 
Advocacy consists of relationship building with policy makers to ensure that water quality standards are upheld, and that public funding is allocated for water protection and restoration. Education is carried out in a variety of ways including classes, activities with teenagers during summer camps, and online webinars held for activists. A group that is specifically identified by women in these organizations are children in the $\mathrm{K}-12$ system. Women claim that for behavioral change to happen it is important to engage children in these conversations regarding the importance of clean safe water at an early age. In this way, they try to compensate for the lack of environmental education offered in schools by making explicit the link between humans and the degradation of the environment. They say that students tend to be interested and receptive toward science and information around water, and women hope that children can relay the message back home, having potential educational spillover effects on their parents.

Programming is constant in these organizations, particularly NGOs, as an opportunity to fundraise while also keeping public attention and interest in water quality and preservation up. The most successful programming activities are summer festivals held in different watersheds that include vendor stands, $5 \mathrm{~K}$ runs, or paddling competitions that provide an avenue for fun, while also spreading environmental knowledge. Organizing often includes reactive actions spurred by the impendency of passing threatening legislative bills or environmental disasters. In these instances, these organizations call out to their memberships with action alerts such as calling their representatives, making donations, and participating in protests.

\section{Financial impediments}

Women interviewed recognized that, although in some cases men were instrumental in introducing them to activism and were allies, mostly in the past, the work of environmental stewardship in West Virginia seems to be perceived as mostly women's work. This general perception is reflected in the fact that the majority of the interviewees are working on a volunteer basis for their organizations. Some engaged in these organizations after their children left home for college or after they retired. Others are active in the environmental sector at night or during weekends while working full time jobs.

Many suggested that women are leading because of their experience and societal expectations as nurturers and caretakers. Women also noted that it is culturally expected for them to be caretakers and in lower paid or volunteer positions. When asked, women struggled to name men who are involved at the same capacity in areas of community organizing and volunteer work. Often men were cited as part of the problem, with many women noting that men were more likely to be in decision-making positions, e.g., lawyers, professors, and doctors studying environmental topics related to developments that women are fighting against. Additionally, women leading environmental organizations who hired as a dimension of their leadership positions consistently stated that men's requests for salary and benefits were higher than women. Men are also perceived as benefitting financially and socially from this differential status, i.e., higher pay and higher positions as they are being listened to by legislators and industry more than women: a clear indication of engrained homosociality.
Few women have paid positions. Some started volunteering on an AmeriCorps VISTA position and were then hired on specific projects later staying with the organization. They all maintain that they reached their current position because of their persistency and leadership skills they had gained in their organizations throughout time.

However, those that have paid positions often assert the following:

I feel really blessed that I do this work and actually get paid. I meet a lot of talented, really smart people that work really hard and sometimes I feel like I should give up my job and let somebody else have it (laughs). (Interviewee \#26, 16 September 2017)

However, women argue that, even when paid, their positions are less monetarily rewarding and less powerful than those of industry lobbyists.

We don't have many on our side who are professionally paid. Me, Ann, we're still trying to get Ann some money. There's just a handful of us that can make a living doing this work, versus the men I see who are able to do that not in environmental, but those who are lobbying the other side. I don't know if you've heard the phrase "good ol' boys"? (Interviewee \#5, 2 May 2017)

On the other hand, some say,

I think the organizations when you do get a salary, it's not very high. Women would be more likely to take it. Or, say maybe these are more flexible jobs and they're more easy to accommodate homemaking responsibility. (Interviewee \#2, 25 April 2017)

Yet, this last statement does not ring true for all women. Some state that the financial sustainability of their organization is a major worry and a source of stress and that during fundraising events they have to work overtime. The main reason women maintained their engagement, although unpaid, is the strong ties they hold with their identity as water activists: many would not know how to describe themselves if this element of their identity were to be taken away.

\section{Opposition}

Almost every interviewee mentioned that their gender has played against them in one instance or another. Some women have been harassed at protests, while doing outreach in schools, or by stalkers. That has not discouraged them from continuing their work.

Women are the main environmental lobbyists during the West Virginia legislative session. They argue for increasing water quality standards, but more often fight against the consistent attempts to lower these standards allegedly geared at attracting extractive industries. Legislators historically have been aligned with the industry to the detriment of women.

I actually had a legislator this year that was totally rude to me and kept saying that... "there's that girl that's against everything I'm for." I'm not against everything, I want people to have jobs. 
This statement is representative of a general attitude toward women in the environmental sector in West Virginia who are presented as "rogue environmentalists" or "against everything that brings economic development" by industry representatives (see Mishkin 2019).

Women try to mitigate opposition to their work by spending time creating rapport and striving to find common ground with local stakeholders who do not support their work. Topics they use to find common ground to make people understand the fragility of the environment in West Virginia and people's interconnectedness with nature are the 2014 Elk River chemical spill, the 2016 floods, and dire working conditions and health consequences of being a coal miner.

Building relationships is something that women are proud of. They say that they strive to create rapport with locals, industry representatives, fellow activists, lobbyists, and legislators in the Capitol through time, experience and consistency. Seeking compromise and balance, understanding all sides of an issue, especially the one that is opposed to you. One rule is that we do not attack people. Women rather try to make individual connections getting to know something personal about the person they are talking to e.g. origin, children, family, hobbies, so that they have something to break the ice with.

\section{But still, when I think about what we call "the other side," I wish I had better language because it's a lot of "us" and "them" in this work and "winning" and "losing" and I'm trying to figure out how to get away from that language because the implication for is that if we win, someone loses. But when I think about the other side, and the lobbyists for industry interest, it's very male dominated. (Interviewee \#3, 25 April 2017)}

There is a clear link between water and women across organizations in West Virginia, in private consulting firms, governments, and NGOs. Some women speculate that it might be because men are closer to the extractive industry and women "feel more of a tie to environmental and health concerns."

\section{CONCLUDING DISCUSSION}

Grounded on original ethnographic data, I examine nurturing approaches, financial impediments, and opposition that women water stewards enact, experience, and overcome in their care work. This article, which departs from stewardship literature, previous studies on women's environmental activism in Appalachia, and current societal representations of West Virginia and its women, makes three main contributions.

First, advancing from Enqvist et al.'s (2018) care-agencyknowledge framework of stewardship, this article contributes to the study of the dimension of care. Specifically, I show that West Virginia women are stewards because of their long-term thinking and heightened sense of ethics and responsibility toward future generations (see also Bennett et al. 2018). In this sense, women enact collective ecological management through civic ecologic practices whose goal is to restore and preserve water quality for local benefit (Krasny and Tidball 2015). The data presented add important original material to this literature by bringing to the forefront women's "nurturing approaches" (Enqvist et al. 2018:25), but also the financial impediments and opposition they are faced with, hampering them from exercising institutional stewardship (see also Bennett et al. 2018). Following Enqvist et al.'s (2018:25) framework definition of care as "understood broadly as 'looking after' something or someone," women water stewards show that care can be enacted even given the prevalence of unpaid work, the need to engage in politics and activism during free time, and the pervasive opposition they encounter among other stakeholders. Women's nurturing approach to water stewardship, I argue, extends the realm of care work beyond the home and the workplace into the environment. They, in fact see water restoration and preservation as their responsibility toward future generations (Enqvist et al. 2018, Worrell and Appleby 2000). For instance, they carry out education activities geared toward $\mathrm{K}-12$ students in order to "provide a route to bring[ing] about broad-scale behavioral changes and 'reconnection to the biosphere"" (Folke et al. 2011, as cited in Enqvist et al. 2018:25). Their motivation is value laden and, I contend, is gendered because women approach their stewardship role from the standpoint of care for their wider community and future generations. Additionally, the opposition they face is also gendered. This environmental unaccounted care work that women carry out is further taxing because they face opposition, which, together with the meager financial support they and their organizations can count on, are indicative of limited financial and social resources (see also Svendsen and Campbell 2008, Bennett et al. 2018). By showing how women persist in their stewardship, this article exemplifies how also the contrary of "financial incentives (and) sense of belonging" (Enqvist et al. 2018:25), i.e., low or no pay, opposition, and exclusion, do still instill care in stewards. Accordingly, by focusing on the care dimension of stewardship, this work shows how being called "against jobs" and having limited or no financial support are not necessarily deterrents to the "rationalized ideals of stewardship" (Enqvist et al. 2018:25).

Second, by focusing on care and on women's environmental care work, this article reveals that women's approach is diametrically opposite to that of the extractive industry, which has historically made financial gains that have not resulted in development, but rather in the further impoverishment of Appalachia (Bell and Braun 2010, Willow and Keefe 2015). By resisting the plundering of Appalachia, women are portrayed by industry, lobbyists, and industry-aligned politicians as against job creation and the resurgence of coal in Appalachia. Women heading environmental and watershed organizations bear the brunt of men's antagonistic environmental discourse as they actively work to remediate the consequences of the extractive industry's practices. Women's viewpoints and data are disregarded by the legislature and not taken into full account by male industry representatives. As all actors need to participate equally for collective ecological management to attain sustainability, this sided consideration for industry's interests effectively excludes or limits women water stewards' participation in environmental decision-making processes (see also Dyer 2018). In sum, the extractive industry is masculine in its composition and behavior against women: a clear indication of its homosociality. Men's dominance in the extractive industry and women's prevalence in water stewardship demonstrate that these homosocial networks are situated and performed through place-based politics and movements interrogating the dichotomy of "job vs. environment," which has become ever harsher since the 2016 presidential election and the 
relaxation of environmental and safety standards for the extractive industry.

Third, by analyzing the case of homosociality in water stewardship, this article adds to the literature documenting women's environmental activism in Appalachia (e.g., Bell and Braun 2010, Smith 2015). Although this literature has long shown the crucial role that women have played in the environmental and labor movements in West Virginia, it has not counteracted the still existing stereotypes and essentializing of Appalachian women as passive, ignorant, bound to their homes, victims of overdoses, sexual trafficking, and violent marital relationships (Lofton 2018). This article contributes to challenging those stereotypes by showing that women are outspoken and active for the preservation of water for future generations. The decline of the coal industry has however not fundamentally shaken the homosocial networks and practices that characterize West Virginia historically. I contend that especially nowadays, with the relaxation of environmental regulations, is it paramount for research to show that there exists those that, against material and societal odds, persist in their care for water. More work along these lines is critically needed to continue debunking the essentialization of this region as poor, dependent, and mined and to decolonize Appalachia from within.

Responses to this article can be read online at: http://www.ecologyandsociety.org/issues/responses. php/11555

\section{Acknowledgments:}

This work would not have been possible without the participation and support of all the WVWAWAs (WV women in water) that I have had the honor of meeting, working with, and being inspired by. I extend my appreciation to my former and current graduate students Bethani Turley, Elizabeth Dever, and Brandon Rothrock for helping me with data transcription, analysis, proof-reading, referencing, and formatting. This piece is dedicated to the memory of April Pierson-Keating, a true WVWAWA whose legacy is and will be an inspiration for water stewards across Appalachia.

\section{Data Availability Statement:}

The data that support the findings of this study are available on request from the corresponding author $M A C$. The data are not publicly available because they contain information that could compromise the privacy of research participants

\section{LITERATURE CITED}

Barry, J., and K. Smith. 2008. Landscape, politics, labour, and identity: stewardship and the contribution of Green Political Theory. Landscape Research 33(5):565-585. https://doi. org/10.1080/01426390802323781

Bell, S. E., and Y. A. Braun. 2010. Coal, identity, and the gendering of environmental justice activism in central Appalachia. Gender \& Society 24(6):794-813. https://doi.org/10.1177/0891243210387277
Bennett, N. J., T. S. Whitty, E. Finkbeiner, J. Pittman, H. Bassett, S. Gelcich, and E. H. Allison. 2018. Environmental stewardship: a conceptual review and analytical framework. Environmental Management 61:597-614. https://doi.org/10.1007/s00267-017-0993-2

Bird, S. R. 1996. Welcome to the men's club: homosociality and the maintenance of hegemonic masculinity. Gender \& Society 10 (2):120-132. https://doi.org/10.1177/089124396010002002

Caretta, M. A. 2016. Member checking: a feminist participatory analysis of the use of preliminary results pamphlets in crosscultural, cross-language research. Qualitative Research 16 (3):305-318. https://doi.org/10.1177/1468794115606495

Dyer, M. 2018. Transforming communicative spaces: the rhythm of gender in meetings in rural Solomon Islands. Ecology and Society 23(1):17. https://doi.org/10.5751/ES-09866-230117

Enqvist, J. P., S. West, V. A. Masterson, L. J. Haider, U. Svedin, and M. Tengö. 2018. Stewardship as a boundary object for sustainability research: linking care, knowledge and agency. Landscape and Urban Planning 179:17-37. https://doi. org/10.1016/j.landurbplan.2018.07.005

Hammarén, N., and T. Johansson. 2014. Homosociality: in between power and intimacy. SAGE Open 4(1). https://doi. org/10.1177/2158244013518057

Hoback, C. 2017. What lies upstream. [Documentary film]. Hyrax Films. [trailer online] URL: http://www.whatliesupstream.com/

Holgersson, C. 2013. Recruiting managing directors: doing homosociality. Gender, Work \& Organization 20(4):454-466. https://doi.org/10.1111/j.1468-0432.2012.00595.x

Joshi, D. 2014. Feminist solidarity? Women's engagement in politics and the implications for water management in the Darjeeling Himalaya. Mountain Research and Development 34 (3):243-254. https://doi.org/10.1659/MRD-JOURNAL-D-13-00097.1

Krasny, M. E., and K. G. Tidball. 2015. Civil ecology: adaptation and transformation from the ground up. MIT Press, Cambridge, Massachusetts, USA. https://doi.org/10.7551/mitpress/9780262$\underline{028653.001 .0001}$

Lofton, K. L. 2018. A profile of those who fatally overdose in WV. WV Public Broadcasting, 23 January. [online] URL: http:// wvpublic.org/post/new-report-profile-those-who-fatally-overdosewv\#stream $/ 0$

Mandara, C. G., A. Niehof, and H. van der Horst. 2017. Women and rural water management: token representatives or paving the way to power? Water Alternatives 10(1):116-133.

Mishkin, K. 2019. Lobbyist: 'Rogue environmental groups' standing in way of building pipelines. Charleston Gazette Mail, 8 January. [online] URL: https://www.wvgazettemail.com/news/ lobbyist-rogue-environmental-groups-standing-in-way-of-buildingpipelines/article 85df5926-f919-5ef1-930a-194d539de552.html

Nobel, J. 2018. A progressive revolt is brewing in West Virginia. Rolling Stone, 13 February. [online] URL: https://www. rollingstone.com/politics/news/a-progressive-revolt-is-brewing-inwest-virginia-w516647

Smith, B. E. 2015. Another place is possible? Labor geography, spatial dispossession, and gendered resistance in central 
Appalachia. Annals of the Association of American Geographers 105(3):567-582. https://doi.org/10.1080/00045608.2014.924731

Svendsen, E. S. and L. K. Campbell. 2008. Urban ecological stewardship: understanding the structure, function and network of community-based urban land management. Cities and the Environment 1(1):1-32. [online] URL: https://www.nrs.fs.fed.us/ pubs/3777

Willow, A. J., and S. Keefer. 2015. Gendering extraction: expectations and identities in women's motives for shale energy opposition. Journal of Research in Gender Studies 5(2):93.

Worrell, R., and M. C. Appleby. 2000. Stewardship of natural resources: definition, ethical and practice aspects. Journal of Agricultural and Environmental Ethics 12(3):263-277. 